\title{
The Potential Influences of the Global Strategy on the Conventional Legislative and Regulatory Measures
}

\author{
Ayman Abdel Tawab \\ Department of Architectural Engineering, Faculty of Engineering, Tanta University, Tanta, Egypt \\ Email address: \\ a_g_a_abdeltawab@yahoo.co.uk

\section{To cite this article:} \\ Ayman Abdel Tawab. The Potential Influences of the Global Strategy on the Conventional Legislative and Regulatory Measures. Landscape \\ Architecture and Regional Planning. Vol. 4, No. 3, 2019, pp. 36-52. doi: 10.11648/j.larp.20190403.11
}

Received: September 8, 2019; Accepted: October 7, 2019; Published: October 26, 2019

\begin{abstract}
Nominating heritage properties for listing as World Heritage Sites has become more challenging with the advent of the Operational Guidelines of 2005 that have construed the prerequisites of the Global Strategy. According to the Guidelines of 2005, States Parties, to the World Heritage Convention, are urged to nominate properties for listing as World Heritage Sites that fall under particular under-represented heritage categories and are requested to verify the availability of the legislative and regulatory measures that guarantee the protection of these properties. The main aim of this paper was to evaluate the influences of the Global Strategy on the conventional legislative and regulatory measures that were used before the adoption of the Global Strategy to support nominations for listing properties as World Heritage Sites. The empirical study approached this issue by selecting a non-probability purposive sample of eight British World Heritage Sites that represent the pre-Global Strategy and the post-Global Strategy World Heritage Sites. Developing and analyzing a database of the data provided by the management plans of the selected case studies was the research tool that was adopted to conduct the empirical study. The most significant finding of this study unveiled the very limited influences of the Global Strategy on the conventional legislative and regulatory measures that were used earlier to support nominations of heritage properties for listing as World Heritage Sites. The study suggests replacing the inefficient non-statutory mechanisms that are used to provide protection for the heritage properties in the adopted case studies by further developed statutory ones.
\end{abstract}

Keywords: Heritage Management, World Heritage Sites, Global Strategy, Management Plans, Cultural Landscapes, Historic Towns

\section{Introduction}

Inscribing properties on the World Heritage List, WHL, has been associated with a group of prerequisites. States Parties, to the World Heritage Convention, have to justify the Outstanding Universal Value, OUV, of the properties they nominate for listing as World Heritage Sites, WHSs. The nominated properties should also meet the conditions of authenticity, if they are nominated under criteria (i) to (vi). All these properties have to satisfy the conditions of integrity as well. Finally, States Parties have to prove their possession of adequate legislative and regulatory measures that guarantee the protection of the nominated properties [1].

In 1994, the World Heritage Committee adopted the Global Strategy for a balanced, representative and credible World Heritage List [2]. Consequently; the Operational
Guidelines, OGs, have undergone significant amendments that have been materialized by the version of the $1^{\text {st }}$ of February 2005. These amendments involve the recommendation to nominate properties that fall into underrepresented categories of heritage properties. Applying an order of priority, which gives priority to un-represented categories of heritage properties, also reflects these amendments [3]. Responding to the previous challenges imply that States Parties might need to develop the conventional legislative and regulatory measures that they used to depend on as a support for their nominations of properties for listing as WHSs.

The Tentative Lists submitted by many States Parties, such as Egypt, seem to reflect a considerable response to the previous challenges. The Egyptian Tentative List includes many cultural landscapes and itineraries [4], which represent under-represented and new categories of heritage properties. 
The inclusion of these properties on the Egyptian Tentative List reflects the response to the challenges of the Global Strategy. Many other States Parties, such as the United Kingdom, have already begun to inscribe many other heritage properties that represent either cultural landscapes or industrial heritage, both of which represent two new categories of heritage properties that are under-represented on the WHL. The listing of these new and under-represented categories of heritage properties on the WHL also reflects the response to the challenges of the Global Strategy. In spite of the previous strengths, the legislative and regulatory measures that are available for these States Parties, and other States Parties, seem to be in a serious need for further developments in order to efficiently respond to the challenges of the Global Strategy.

Several previous publications addressed the various debates in connection with the challenges and the historic origins of the Global Strategy. These publications also discussed the new prerequisites related to the nomination and management of heritage properties for listing as WHSs that were introduced by the Global Strategy, and the challenges that the implementation of the Global Strategy still faces. Aplin [5] discusses the prerequisites established by the Global Strategy and its encouragement for States Parties to nominate properties for listing as WHSs, which represent particular under-represented categories of heritage properties, such as industrial heritage. However, he emphasizes that some properties that were inscribed on the WHL before the adoption of the Global Strategy already represent these under-represented categories, particularly industrial heritage. He cites a relevant example in the United Kingdom, which is Ironbridge Gorge, and which is an industrial heritage site that was inscribed on the WHL in 1986 before the adoption of the Global Strategy.

Gfeller [6] discusses the historic origins of the Global Strategy and indicates that the Global Strategy emerged from lengthy prior discussions that began as early as the 1980s. This fact clarifies Aplin's previous remark [5] concerning the listing of properties representing the under-represented categories as WHSs prior to the adoption of the Global Strategy. Gfeller [6] also indicates that several new actors influenced the core notion of the Global Strategy and that most of the contributors to the Global Strategy came from regions, such as Australia, and disciplines, such as anthropology. She adds that those new actors introduced new ideas in the debates concerning the Global Strategy. Gfeller [6] also cites other scholars who provided some of the most comprehensive discussions on the historic origins of the Global Strategy, particularly Christina Cameron and Mechtild Rössler. Labadi [7] provides a critical analysis of the implementation of the Global Strategy and highlights some of the successes and the problems and pitfalls associated with the implementation of the Global Strategy. She also suggests some future directions to resolve the imbalances of the WHL.

This paper contributes to the previous discussions on the historic origins and the challenges of the implementation of the Global Strategy. This paper elaborates on other challenges associated with the implementations of the Global Strategy that do not seem to have been thoroughly discussed through the previous relevant publications. These challenges are related mainly to the States Parties' need to develop their conventional legislative and regulatory measures in order to provide the required protection for the heritage properties that represent the new and under-represented categories of heritage properties. Labadi [7] also indicates that the national legislation concerned with the protection of cultural heritage in some States Parties, particularly Egypt, requires further development in order to provide a statutory protection for the heritage of the twentieth century. Labadi's previous argument emphasizes the significance of the subject of this paper.

\section{Theoretical Backgrounds}

\subsection{The Challenges of the Global Strategy}

The Glossary of World Heritage Terms provides the following definition of the Global Strategy: "the Global Strategy is a conceptual framework devised to ensure the representativeness and credibility of the World Heritage List" [8, p. 20]. The main objective of the Global Strategy is to guarantee that the WHL represents the diversity of the world's cultural and natural sites that enjoy OUV [2]. Resolving the imbalances of the WHL has been among the motives that led to the adoption of the Global Strategy. These imbalances exist on the geographical and the typological levels. On the geographical level, Europe's heritage is considered over-represented, in relation to all the other UNESCO regions' heritage [9]. On the typological level, some types of heritage properties are over-represented, such as cultural sites, in relation to natural and mixed sites [2]. Historic towns, religious buildings and elitist architecture are other over-represented types of heritage properties [9]. On the other hand; prehistoric sites, modern heritage, vernacular architecture [9], industrial heritage and archaeological sites are under-represented types of heritage properties [5]. In addition to the previous under-represented types, there are other new themes of heritage properties, the listing of which can contribute towards restoring the balance of the WHL. These new themes involve two major groups, which are "human coexistence with the land" and "human beings in society" [10]. Cultural landscapes can be considered among these new under-represented themes.

The Tentative Lists submitted by all the States Parties to the Word Heritage Convention and the amendments carried out to the OGs of 2005 represent the key outcomes of all the efforts that were undertaken to address the challenges of the Global Strategy. The amendments carried out to the OGs of 2005 involve requesting over-represented States Parties to slow down their nomination rates by nominating only the properties that fall into under-represented categories, or by linking each of their nominations with one of the nominations that the under-represented States Parties make. The amendments also involve giving the maximum propriety 
to the nominations that the nil-sites States Parties make. The nominations of the properties that belong to underrepresented categories are given the second priority [3].

\subsection{Over-Represented Categories of Heritage Properties}

Pre-Global Strategy WHSs largely represent the overrepresented categories of heritage properties. World Heritage Cities [11] and elitist architecture represent the pre-Global Strategy heritage properties, and are considered overrepresented categories [9]. Although they represent an overrepresented category of heritage properties, many potential World Heritage Cities have not been inscribed yet, despite the fact that they enjoy an undeniable OUV. Furthermore, World Heritage Cities of some States Parties, such as Egypt, are still under-represented. Only one Egyptian World Heritage City is inscribed as a WHS, which is "Historic Cairo" (Figure 1), despite that there are other potential World Heritage Cities, which deserve the promotion to the WHS status. The Tentative Lists of some over-represented States Parties still involve many potential World Heritage Cities, such as the American Tentative List that involves five historic districts [4]. Cultural WHSs that are located inside urban contexts can be classified as "historic cities and towns inscribed as such on the WHL" or "WHSs in an urban context". "City of Valletta", in Malta, is an example of the former group, which represents World Heritage Cities, while "Abu Mena", in Egypt, represents the "WHSs in an urban context" group [12].

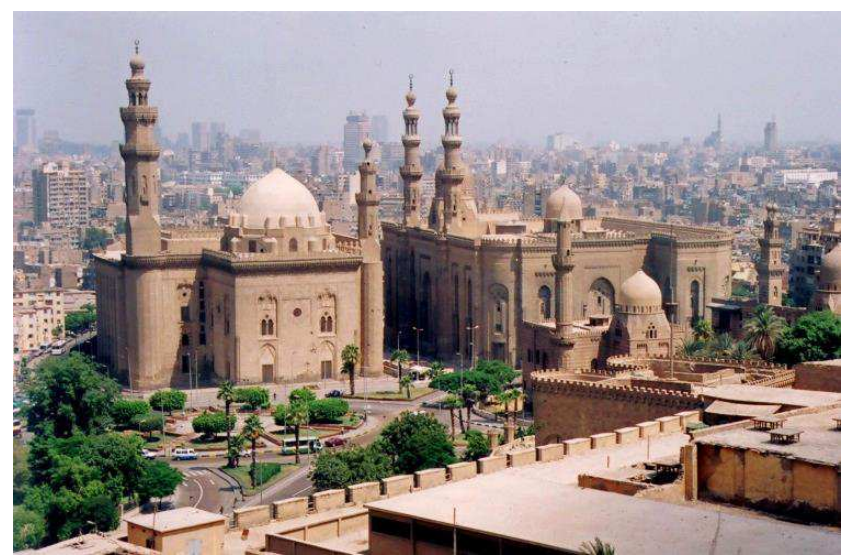

Figure 1. Sultan Hassan Mosque and al-Rifa'i Mosque inside "Historic Cairo" WHS (Source: the author).

Many challenges usually encounter the trials to safeguard World Heritage Cities. The need for special provisions, which include legislation and regulations that help in controlling the quality of new urban development introduced inside these areas might be one of the major challenges. There are some programmes that aim at facilitating the conservation of World Heritage Cities, such as the World Heritage Cities Programme. Through this programme many pilot projects have been initiated, such as the pilot project in "Historic Cairo". These programmes also include the World Heritage Tourism Programme and the World Heritage Partnership Initiative (WHPI) [11]. Elitist architecture, which is an example of the over-represented categories of heritage properties, can be classified into two groups, which are "properties associated with religious buildings" and "properties associated with the gentry". "Westminster Palace, Westminster Abbey and Saint Margaret's Church" is an example of the former group, while the "Tower of London" is an example of the latter.

\subsection{Under-Represented Categories of Heritage Properties}

Post-Global Strategy WHSs are more likely to represent the under-represented categories of heritage properties. Cultural landscapes and modern heritage are among the major under-represented categories. Only 30 WHSs are inscribed under the cultural landscapes category [13], and only 12 WHSs belong to the modern heritage category [14].

Tentative Lists of some States Parties, such as Egypt, still ignore many significant heritage properties that deserve the listing on the WHL as cultural landscapes. The Egyptian Tentative List involves three oases, one of which is "the Northern Oases, the Western Desert" property, which are considered cultural landscapes [4]. Nevertheless, the Egyptian Tentative List has ignored other significant heritage properties that represent cultural landscapes, which reflect the diverse heritage of the desert regions, such as "El-Qasr and Bagawat" [15]. The Egyptian Tentative List involves a single heritage property that partially represents modern heritage, which is "Alexandria, ancient remains and the new library" [4] (Figure 2, Figure 3). However, the Egyptian Tentative List ignored many significant heritage properties that deserve the listing on the WHL as recent heritage, such as the works of Hassan Fathy. Many recent heritage properties that are designed by the pioneers of the modern architectural movement have been inscribed as WHSs representing modern heritage, such as the "Works of Antoni Gaudi" WHS in Spain [16].

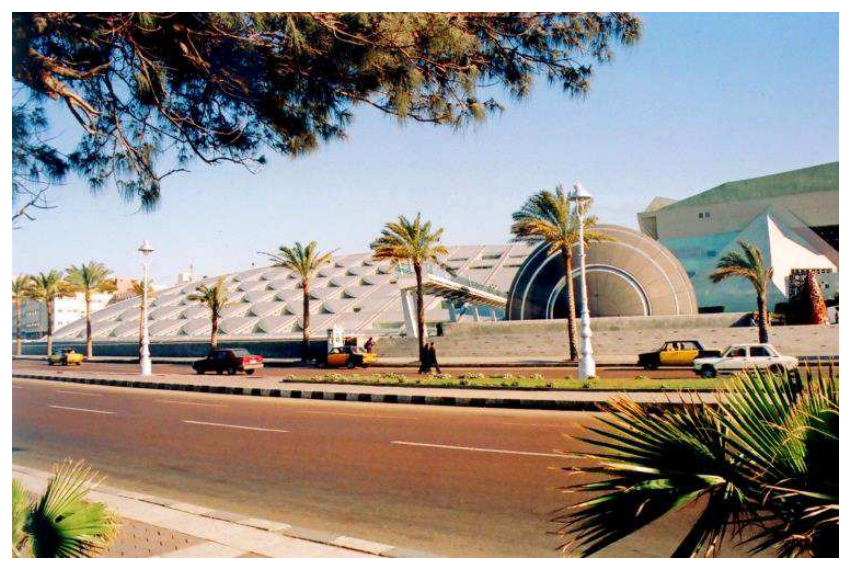

Figure 2. Bibliotheca Alexandrina, which represents a key element of the "Alexandria, ancient remains and the new library" potential WHS (Source: the author).

Article 47 of the OGs provides the following definition of cultural landscapes: "Cultural landscapes are cultural properties and represent the "combined works of nature and man" designated in Article 1 of the Convention. They are 
illustrative of the evolution of human society and settlement over time, under the influence of the physical constraints and/or opportunities presented by their natural environment and of successive social, economic and cultural forces, both external and internal" [1, p. 19]. There are three subsidiary categories of cultural landscapes. The first involves the landscapes designed and created intentionally by man. The second involves the organically evolved landscapes and is classified into two sub-categories, which are the relict (or fossil) landscapes and the continuing landscapes, while the third involves the associative cultural landscapes [1].

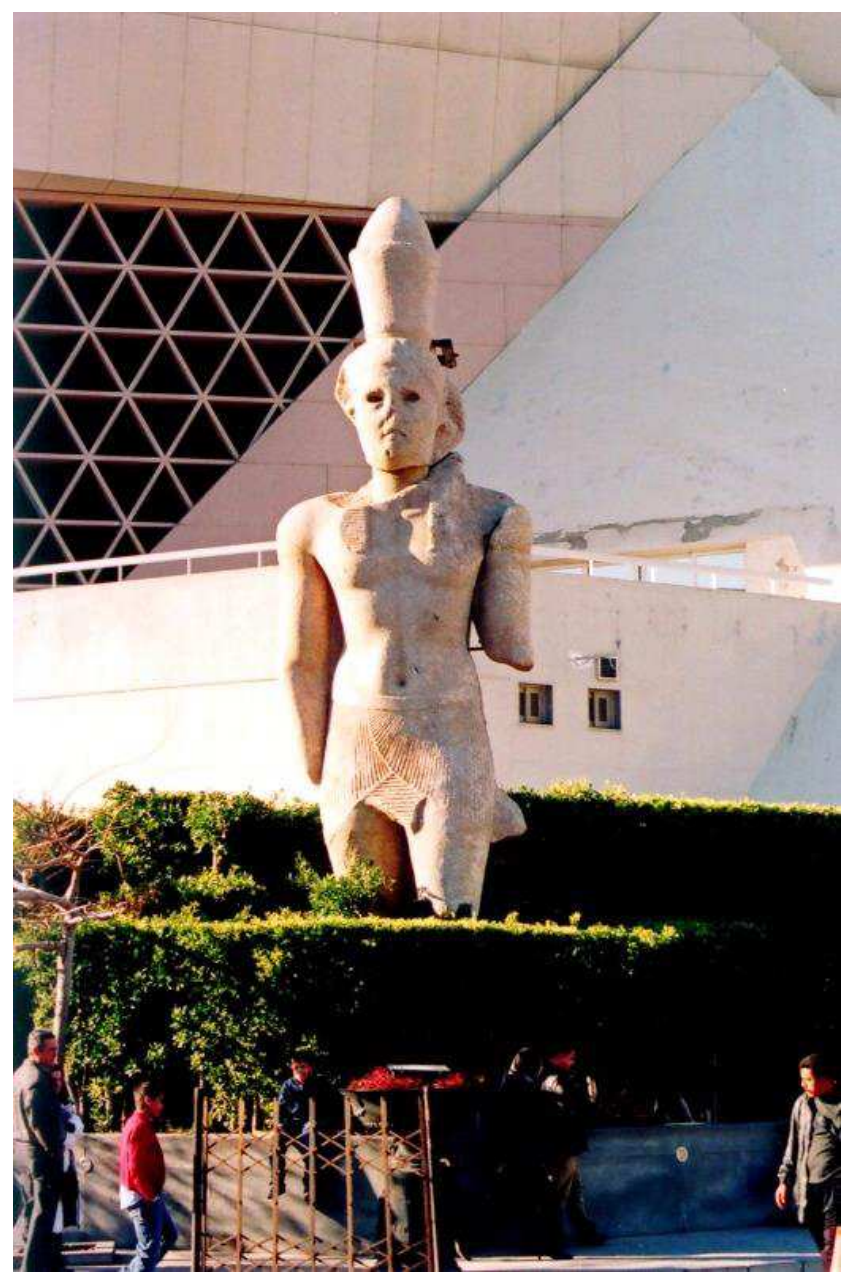

Figure 3. The statue of Ptolomey II Philadelphus, who inaugurated the ancient library of Alexandria, and which stands in the Plaza of the new Bibliotheca Alexandrina. Having been lifted from the neighbouring Eastern Harbour, the statue embodies the new library's association with the ancient remains that are submerged underneath the harbour (Source: the author).

Heritage properties inscribed on the WHL as cultural landscapes have a group of characteristics. The most common characteristic is the existence of towns and villages within the boundaries of these properties. The existence of water sources; such as rivers, lakes and sea water, is the second characteristic. Religiosity and the existence of topographical features, such as mountains, are other characteristics [17]. The WHL contains some properties inscribed as cultural landscapes, such as "Royal Botanic
Gardens, Kew" WHS in the United Kingdom [18]. There are other properties that have been inscribed as cultural WHSs, before the recognition of the notion of cultural landscapes, which can be re-inscribed as cultural landscapes. "Ancient Thebes with its Necropolis" WHS in Egypt is an example of these properties [17].

Modern heritage, which represents another underrepresented category of heritage properties, can be classified as either modern heritage properties or industrial heritage properties [19]. The properties that represent this category might be either $19^{\text {th }}$ or $20^{\text {th }}$ century built heritage. The notion of modern heritage can be expanded to incorporate other subsidiary themes such as colonialism, mobility, new towns, rebuilt towns, and open spaces and landscapes [14]. Many challenges face the conservation of modern heritage. The inefficient relevant legislative measures and the public limited appreciation are examples of these challenges [14]. Modern heritage has not been fully investigated or analyzed [20]. The narrow look towards colonial heritage, as something to be ashamed of or angry about, is another major challenge [21]. The "Bauhaus and its Sites in Weimar and Dessau", in Germany, is an example of the WHSs that represent modern heritage. "New Lanark", in the United Kingdom, is another example of the WHSs that represent industrial heritage [19].

\subsection{The Legislative and Regulatory Measures}

Within their nomination documents, and their appended management plans, the States Parties that nominate properties for listing as WHSs have to demonstrate the sufficiency and efficiency of the legislative and regulatory measures that they possess. The principal function of these measures should be to guarantee the protection of the nominated properties against any potential new urban development that might negatively influence their OUV, or their authenticity and integrity. These measures also involve the institutional and contractual measures. States Parties should also guarantee the efficient implementation of all these measures [1].

The legislative measures involve aspects, such as the relevant legislation and the various protecting statuses that provide an official protection for the nominated properties. On the other hand, the regulatory measures involve a wide range of aspects. These regulatory measures involve the administrative and practical arrangements that can be adopted for the conservation and management of the States Parties' heritage properties. These measures should also address the relevant organizations and their basic features, such as their duties and responsibilities. These duties involve, for instance, undertaking research and survey works, providing grants and advice, and sites maintenance and management. The features of these organizations also involve whether they are the official governmental agencies or not and whether their responsibilities are limited to the ownership of the heritage property or that they also involve the management aspects of the property [5].

Annex 5 of the OGs addresses the various aspects of the 
legislative and regulatory measures in further depth. It indicates that the fifth section of the nomination document, which should contain nine sections, has to be dedicated to the protection and management subject. Through this section, States Parties have to list all the available legislative, regulatory, contractual, institutional and/or traditional measures that can contribute to the protection of the nominated property. Section five should address 10 subsidiary subjects; which are the ownership, the protective designations, the means of implementing the protective measures, the existing plans related to the municipality and the region in which the nominated property is located, the property's management plan or any other management system, the sources and level of finance, the sources of expertise and training in conservation and management techniques, the visitors' facilities and statistics, the policies and programmes related to the presentation and promotion of the property, and the levels of staffing that might involve the professional, technical or maintenance levels. The first subsidiary subject, which is concerned with the ownership of the heritage property, should indicate the various categories of land ownership related to the concerned property. The second subsidiary subject, which is concerned with the protective designations, should list all the relevant legislation and protecting statuses. Finally, the fourth subsidiary subject, which is concerned with the existing plans, should list all the relevant agreed plans that are concerned with the management of the nominated property and the agencies that have prepared them [1].

Management plans are other key documents that give a sound idea of the States Parties' legislative and regulatory measures, and without which nominations will not be accepted [1]. The submission of management plans with the nomination documents has become compulsory since 1997 [22]. One of the main functions of management plans is to detail how to preserve the nominated property's OUV [1].

\section{The Aim and the Method of the Study}

The main aim of this study was to evaluate the influences of the Global Strategy on the relevant conventional legislative and regulatory measures concerned with the management of WHSs. In addition to the previous objective, the study aimed at evaluating the validity of the following hypotheses:

a. To meet the challenges of the Global Strategy, States Parties have to develop their conventional legislative and regulatory measures.

b. The management of the inscribed WHSs that conform to the prerequisites of the Global Strategy is more complex than the management of the pre-Global Strategy WHSs.

To achieve the previous objectives, an empirical study was carried out. A non-probability purposive sample of 8 British WHSs was selected to carry out the empirical study. The selected sample was planned to represent the pre-Global Strategy and the post-Global Strategy WHSs, equally. Therefore, the selected sample was divided into two groups, each of which contains 4 case studies. The two groups represent both the pre-Global Strategy and the post-Global Strategy WHSs. The first group, which represents the preGlobal Strategy WHSs, involves the "City of Bath", the "Old and New Towns of Edinburgh" (Figure 4), the "Tower of London", and "Westminster Palace, Westminster Abbey and Saint Margaret's Church" WHSs. The second group, which represents the post-Global Strategy WHSs, involves "New Lanark", "Saltaire", "Blaenavon Industrial Landscape", and the "Royal Botanic Gardens, Kew" WHSs. The first group of case studies was also selected so that it represents two overrepresented categories, which are World Heritage Cities and elitist architecture, equally. The second group of case studies was selected so that it represents two under-represented categories, which are modern heritage and cultural landscapes, equally (Table 1) [1, 23-37].

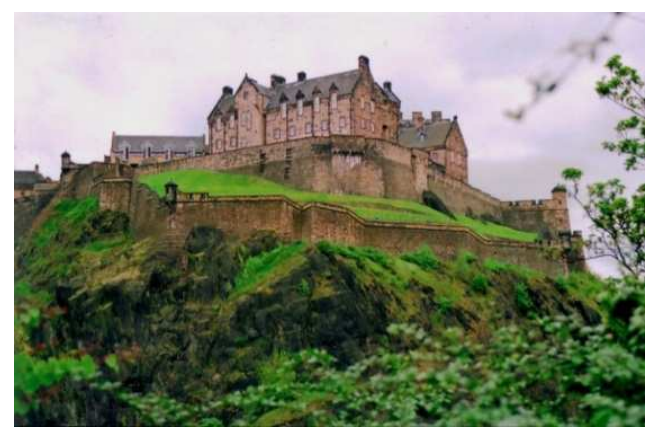

Figure 4. Edinburgh Castle that dominates the urban context of "Old and New Town of Edinburgh" WHS (Source: the author).

Table 1. The basic features of the selected case studies of WHSs.

\begin{tabular}{|c|c|c|c|c|c|}
\hline \multicolumn{2}{|l|}{ Case study } & \multirow{2}{*}{$\begin{array}{l}\text { Location } \\
\text { England }\end{array}$} & \multirow{2}{*}{$\begin{array}{l}\begin{array}{l}\text { Area } \\
\left(\mathbf{k m}^{\mathbf{2}}\right)\end{array} \\
29.00\end{array}$} & \multirow{2}{*}{$\begin{array}{l}\text { Inscription } \\
\text { date }\end{array}$} & \multirow{2}{*}{$\begin{array}{l}\text { Criteria for the inclusion } \\
\text { on the WHL } \\
\text { (i), (ii), (iv) }\end{array}$} \\
\hline & City of Bath & & & & \\
\hline Pre-Global & Old and New Towns of Edinburgh & Scotland & 4.50 & 1995 & (ii), (iv) \\
\hline \multirow{4}{*}{$\begin{array}{l}\text { Strategy case } \\
\text { studies }\end{array}$} & Tower of London & England & 0.073 & 1988 & (ii), (iv) \\
\hline & Westminster Palace, Westminster Abbey and Saint Margaret's Church & England & 0.10 & 1987 & (i), (ii), (iv) \\
\hline & Areas' average (and general summation) & $\mathrm{N} / \mathrm{P}$ & 8.42 & $\mathrm{~N} / \mathrm{P}$ & (i), (ii), (iv) \\
\hline & Blaenavon Industrial Landscape & Wales & 32.9 & 2000 & (iii), (iv) \\
\hline \multirow{4}{*}{$\begin{array}{l}\text { Post-Global } \\
\text { Strategy case } \\
\text { studies }\end{array}$} & New Lanark & Scotland & 1.46 & 2001 & (ii), (iv), (vi) \\
\hline & Royal Botanic Gardens, Kew & England & 1.32 & 2003 & (ii), (iii), (iv) \\
\hline & Saltaire & England & 0.20 & 2001 & (ii), (iv) \\
\hline & Areas' average (and general summation) & $\mathrm{N} / \mathrm{P}$ & 8.97 & $\mathrm{~N} / \mathrm{P}$ & (ii), (iii), (iv), (vi) \\
\hline \multicolumn{2}{|c|}{ Overall areas' average (and overall summation) } & $\mathrm{N} / \mathrm{P}$ & 8.70 & $\mathrm{~N} / \mathrm{P}$ & (i), (ii), (iii), (iv), (vi) \\
\hline
\end{tabular}


Table 1. Continued.

\begin{tabular}{|c|c|c|c|c|c|}
\hline Case study & & $\begin{array}{l}\text { Official } \\
\text { classification }\end{array}$ & Pattern of the Property & Further classification & $\begin{array}{l}\text { representativeness } \\
\text { assessment }\end{array}$ \\
\hline \multirow{5}{*}{$\begin{array}{l}\text { Pre-Global } \\
\text { Strategy } \\
\text { case studies }\end{array}$} & City of Bath & Cultural WHS & World Heritage City & Historic cities and towns & Over-represented \\
\hline & Old and New Towns of Edinburgh & Cultural WHS & World Heritage City & Historic cities and towns & Over-represented \\
\hline & Tower of London & Cultural WHS & Elitist architecture & $\mathrm{N} / \mathrm{P}$ & Over-represented \\
\hline & $\begin{array}{l}\text { Westminster Palace, Westminster } \\
\text { Abbey and Saint Margaret's Church }\end{array}$ & Cultural WHS & Elitist architecture & $\mathrm{N} / \mathrm{P}$ & Over-represented \\
\hline & General summation & Cultural WHS & $\begin{array}{l}\text { World Heritage City and } \\
\text { elitist architecture }\end{array}$ & $\mathrm{N} / \mathrm{P}$ & Over-represented \\
\hline \multirow{5}{*}{$\begin{array}{l}\text { Post-Global } \\
\text { Strategy } \\
\text { case studies }\end{array}$} & Blaenavon Industrial Landscape & Cultural WHS & Cultural landscapes & $\begin{array}{l}\text { Relict (or fossil) organically } \\
\text { evolved landscape }\end{array}$ & Under-represented \\
\hline & New Lanark & Cultural WHS & Modern heritage & Industrial heritage & Under-represented \\
\hline & Royal Botanic Gardens, Kew & Cultural WHS & Cultural landscapes & $\begin{array}{l}\text { Landscape designed and } \\
\text { created intentionally by man }\end{array}$ & Under-represented \\
\hline & Saltaire & Cultural WHS & Modern heritage & Industrial heritage & Under-represented \\
\hline & General summation & Cultural WHS & $\begin{array}{l}\text { Modern heritage and cultural } \\
\text { landscapes }\end{array}$ & $\mathrm{N} / \mathrm{P}$ & Under-represented \\
\hline \multicolumn{2}{|c|}{ Overall summation } & Cultural WHS & $\begin{array}{l}\text { Modern heritage, cultural } \\
\text { landscapes, World Heritage } \\
\text { City, elitist architecture }\end{array}$ & $\mathrm{N} / \mathrm{P}$ & $\mathrm{N} / \mathrm{P}$ \\
\hline
\end{tabular}

[1] The criteria that are adopted for the inclusion of the case studies on the WHL are as follows:

(i) represent a masterpiece of human creative genius;

(ii) exhibit an important interchange of human values, over a span of time or within a cultural area of the world, on developments in architecture or technology, monumental arts, town-planning or landscape design;

(iii) bear a unique or at least exceptional testimony to a cultural tradition or to a civilization which is living or which has disappeared;

(iv) be an outstanding example of a type of building, architectural or technological ensemble or landscape which illustrates (a) significant stage(s) in human history;

(vi) be directly or tangibly associated with events or living traditions, with ideas, or with beliefs, with artistic and literary works of outstanding universal significance. (The Committee considers that this criterion should preferably be used in conjunction with other criteria);

Source: Data analysed by the author from the references $[1$, pp $25-26 ; 23$, p. $5 ; 24$, p. $5 ; 25$, p. $7 ; 26$, p. $5 ; 27$, Part 2 p. $3 ; 28$, p. $5 ; 29$, p. $25 ; 30$, pp $5-6 ; 31$, p. $4 ; 32$, p. $6 ; 33$, p. 4; 34, Section 2 p. 3; 35, p. 5; 36, p. 20; 37, p. 4].

Developing a group of databases that incorporate the relevant required data was the research tool that was adopted to carry out the empirical study. The databases include a primary database in addition to seven subsidiary databases. The subsidiary databases are concerned with the protecting statuses and the relevant legislation that are used for the protection of the heritage of the adopted case studies, the owners of the case studies, the management authorities involved with the management of the case studies, the agreed plans that are adopted on the central government level and those adopted on the local authorities' level for the management of the case studies, and the focus of the relevant policies concerned with the management of the case studies.

The management plans of the case studies were used as the subject of the analysis and the source of the required data. In addition to the management plans, some available nomination documents of some case studies were also taken into consideration. Some aspects of the legislative and regulatory measures, which are provided by the relevant management plans of the case studies, were adopted to carry out the study. The protecting statuses and the relevant legislation that are used for the protection of the heritage of the case studies are the adopted aspects of the legislative measures. The analysis of the protecting statuses that are used to safeguard the heritage of the case studies involves three other subsidiary aspects, which are the legislative position of the adopted protecting statuses, the environmental layer that the protecting statuses influence and the pattern of the protected properties. The analysis of the relevant legislation used to safeguard the heritage of the case studies is involved with the classification of the various adopted legislation into the various legislative groups. On the other hand, the pattern of ownership of the properties in the adopted case studies, the authorities concerned with the management of the case studies and the agreed plans used for the management of the case studies are the adopted aspects of the regulatory measures that are used for the protection of the heritage of the case studies. The analysis of the pattern of ownership involves two other subsidiary aspects, which are concerned with the extent of ownership and the classes of the key owners of the properties in the case studies. The analysis of the management authorities is merely concerned with the classes of the key authorities concerned with the management of the case studies. Finally, the analysis of the agreed plans involves three subsidiary aspects, which are the classes of the agreed plans (on the central government level) and the classes of the agreed plans (on the local authorities' level) that are both used for the management of the case studies, and the focus of the relevant policies concerned with the management of the case studies.

Adopting a group of indicators was another tool used to evaluate the influences of the Global Strategy and the complexity of the management of the adopted case studies. Nine indicators associated with the legislative and regulatory measures were adopted to evaluate the influences of the Global Strategy. Seven other indicators were adopted to 
evaluate the complexity of the management of the adopted case studies (Table 2). Regarding that the management authorities whose duties are not listed in the relevant management plans were not considered as key management authorities. "Old and New Towns of Edinburgh" was considered a pre-Global Strategy WHS despite that it has been inscribed in 1995 because its nomination procedures should have started at least one year earlier.

Table 2. The indicators that were adopted to evaluate the influences of the Global Strategy and the complexity of the management of the selected case studies.

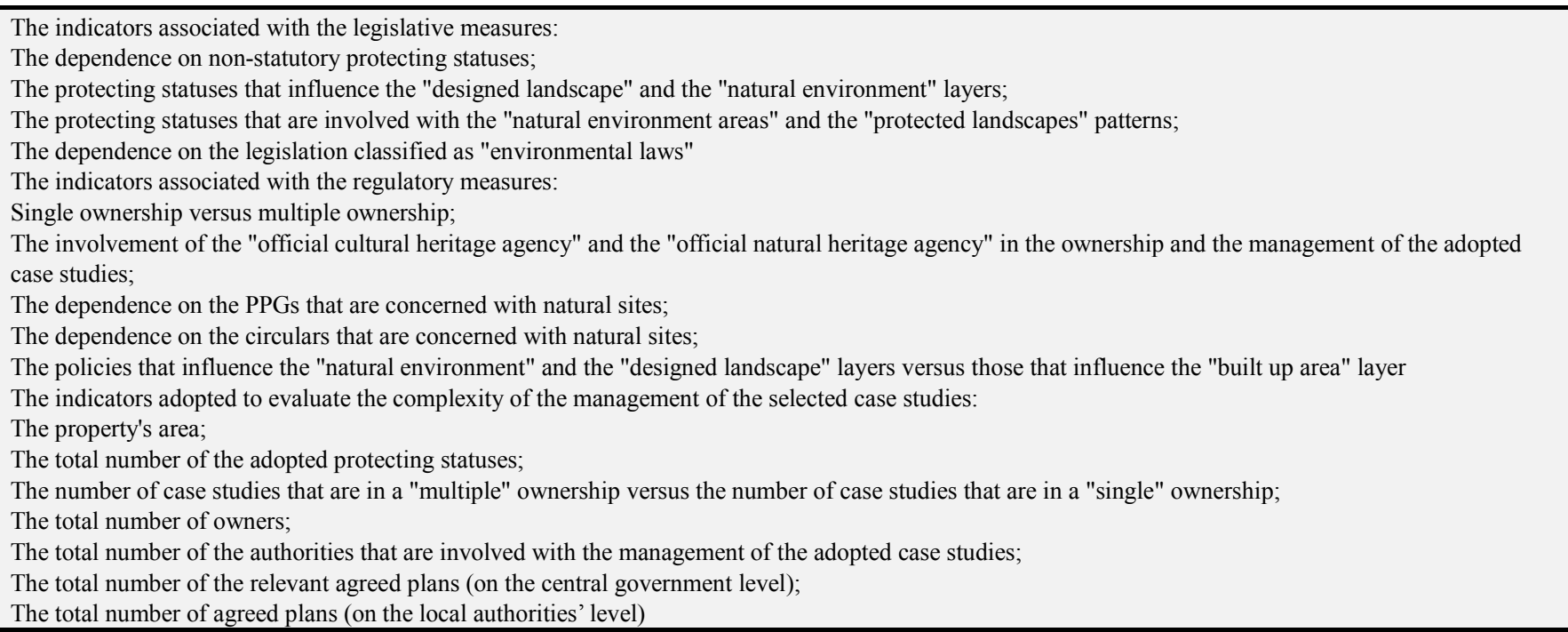

Source: the author.

\section{The Findings and the Discussion}

\subsection{The Basic Features of the Case Studies}

The findings (Table 1) revealed that the adopted eight case studies represent cultural WHSs and that world heritage criteria (i), (ii) and (iv) are adopted to justify the OUV of the pre-Global Strategy case studies, which represent overrepresented categories. Two case studies, which are "City of Bath" and "Old and New Towns of Edinburgh", represent World Heritage Cities, as well as historic cities and towns. On the other hand, the two case studies, which are "Tower of London" and "Westminster Palace, Westminster Abbey and Saint Margaret's Church", represent elitist architecture. The findings (Table 1) also revealed that criteria (ii), (iii), (iv) and (vi) are adopted to justify the OUV of the post-Global Strategy case studies, which represent under-represented categories. Two case studies, which are "New Lanark" and "Saltaire", represent modern heritage, as well as industrial heritage. On the other hand, the two other case studies, which are "Blaenavon Industrial Landscape" and "Royal Botanic Gardens, Kew", represent cultural landscapes. The latter two case studies also represent the two subsidiary categories, which are relict (or fossil) organically evolved landscape and landscape designed and created intentionally by man, respectively.

\subsection{The Influences of the Global Strategy on the Conventional Legislative and Regulatory Measures}

The first aspect that was adopted to explore the influences of the Global Strategy on the conventional legislative and regulatory measures concerned with the management of
WHSs is the protecting statuses used to safeguard the heritage of the case studies. The findings (Table 3) [23, 27, $31,34,36,38,39]$ revealed that 22 protecting statuses are adopted by the management plans of the case studies. These protecting statuses involve, for instance, "Area of Outstanding Natural Beauty", "Area of Recognized Archaeological Potentials" and "Conservation Area". The indicators that were adopted to explore the influences of the Global Strategy on the protecting statuses are "the dependence on non-statutory protecting statuses", "the protecting statuses that influence the designed landscape and the natural environment layers", and "the protecting statuses that are concerned with natural environment areas and protected landscapes". The findings (Table 3) revealed that the management plans of the pre-Global Strategy case studies are more dependent on non-statutory protecting statuses than those of the post-Global Strategy case studies. The findings indicated that the number of the protecting statuses that influence the designed landscape and the natural environment layers, which were adopted by the management plans of the pre-Global Strategy case studies, exceeds the corresponding number of the post-Global Strategy case studies. Eleven protecting statuses that influence the previous layers are adopted to provide protection for the pre-Global Strategy case studies, while only seven protecting statuses are adopted in the case of the post-Global Strategy case studies. The findings also indicated that the dependence of the management plans of the pre-Global Strategy case studies on the protecting statuses concerned with natural environment areas and protected landscapes is equal to that of the management plans of the post-Global Strategy case studies. Twelve of the 18 protecting statuses adopted by the 
management plans of the pre-Global Strategy case studies are concerned with the previous patterns, representing a percentage of $66.67 \%$. On the other hand, six of the nine protecting statuses that the management plans of the postGlobal Strategy case studies adopted are concerned with these patterns, at exactly the same percentage of $66.67 \%$.

The second aspect that was adopted to explore the influences of the Global Strategy on the conventional legislative and regulatory measures is the relevant legislation adopted to provide a statutory protection for the heritage of the case studies. The findings (Table 3) showed that eight acts are adopted to provide the necessary statutory protection for the case studies. These acts involve, for instance, the "Ancient Monuments and Archaeological Areas Act, 1979", and the "Planning (Listed Buildings and Conservation Areas) Act, 1990". The only indicator that was adopted to evaluate the influences of the Global Strategy on the relevant legislation is the dependence on environmental laws. The findings revealed that the management plans of the preGlobal Strategy case studies are more dependent on the legislation that represent environmental laws than those of the post-Global Strategy case studies.

Table 3. An analysis of the relevant legislative measures, concerning the "protecting statuses" and the "relevant legislation".

\begin{tabular}{|c|c|c|c|c|c|}
\hline & & & \multicolumn{3}{|c|}{ The classification of the analysed case studies } \\
\hline & & & \multicolumn{3}{|c|}{ All the analysed case studies } \\
\hline & & & No & $\%$ & The relevant legislation \\
\hline \multirow{11}{*}{$\begin{array}{l}\text { The } \\
\text { protecting } \\
\text { statuses }\end{array}$} & \multirow[t]{2}{*}{$\begin{array}{l}\text { The legislative } \\
\text { position }\end{array}$} & Non-statutory status & 15 & 68.18 & $\begin{array}{l}\text { Area of Outstanding Natural Beauty (AONB), Conservation Area (CA), Listed } \\
\text { Building (LB), National Park (NP), Scheduled Ancient Monument (SAM), } \\
\text { Scheduled Monument (SM), Site of Special Scientific Interest (SSSI) } \\
\text { Area of Recognized Archaeological Potential (ARAP), Area of Special } \\
\text { Archaeological Priority (ASAP), Designed Landscape (DL), Green Belt (GB), } \\
\text { Geological Site (GS), Historic Battlefields (HB), Historic Landscape (HL), Historic } \\
\text { Parks and Gardens (HPG), Important Hillside (IH), Open Space of Outstanding } \\
\text { Landscape Quality (OSOLQ), Site of Borough Importance for Nature Conservation } \\
\text { (SBINC), Site of Metropolitan Importance for Nature Conservation (SMINC), } \\
\text { Strategic View (SV), Urban Wildlife Site (UWS), Wildlife Area (WA) }\end{array}$ \\
\hline & & Total & 22 & 100.0 & \\
\hline & \multirow{3}{*}{$\begin{array}{l}\text { The influenced } \\
\text { environmental } \\
\text { layer }\end{array}$} & Built up area & 7 & $\mathrm{~N} / \mathrm{P}$ & ARAP, ASAP, CA, LB, SAM, SM, SV \\
\hline & & Designed landscape & 5 & $\mathrm{~N} / \mathrm{P}$ & CA, DL, HL, HPG, OSOLQ \\
\hline & & Natural environment & 17 & $\mathrm{~N} / \mathrm{P}$ & $\begin{array}{l}\text { AONB, ARAP, ASAP, CA, GB, GS, HB, HL, HPG, IH, NP, OSOLQ, SBINC, } \\
\text { SMINC, SSSI, UWS, WA }\end{array}$ \\
\hline & \multirow{6}{*}{$\begin{array}{l}\text { The pattern of } \\
\text { the protected } \\
\text { property }\end{array}$} & Archaeological site & 2 & 9.09 & ARAP, ASAP \\
\hline & & Artifact & 3 & 13.64 & LB, SAM, SM \\
\hline & & $\begin{array}{l}\text { Natural environment } \\
\text { area }\end{array}$ & 10 & 45.45 & AONB, GB, GS, IH, NP, SBINC, SMINC, SSSI, UWS, WA \\
\hline & & Protected landscape & 6 & 27.27 & DL, HB, HL, HPG, OSOLQ, SV \\
\hline & & Urban protected area & 1 & 4.55 & CA \\
\hline & & Total & 22 & 100.0 & \\
\hline \multirow{5}{*}{$\begin{array}{l}\text { The } \\
\text { relevant } \\
\text { legislation }\end{array}$} & \multirow{5}{*}{$\begin{array}{l}\text { The legislative } \\
\text { group }\end{array}$} & Archaeological law & 1 & 12.50 & The Ancient Monuments and Archaeological Areas Act, 1979 \\
\hline & & Environmental law & 2 & 25.00 & $\begin{array}{l}\text { The National Parks and Access to the Countryside Act, } 1949 \\
\text { The Wildlife and Countryside Act, } 1981\end{array}$ \\
\hline & & Heritage law & 2 & 25.00 & $\begin{array}{l}\text { The Planning (Listed Buildings and Conservation Areas) Act, } 1990 \\
\text { The Planning (Listed Buildings and Conservation Areas) (Scotland) Act, } 1997 \\
\text { The Civic Amenities Act, } 1967\end{array}$ \\
\hline & & Town planning law & 3 & 37.50 & $\begin{array}{l}\text { The Town and Country Planning Act, } 1971 \\
\text { The Town and Country Planning (Scotland) Act, } 1997\end{array}$ \\
\hline & & Total & 8 & 100.0 & \\
\hline
\end{tabular}

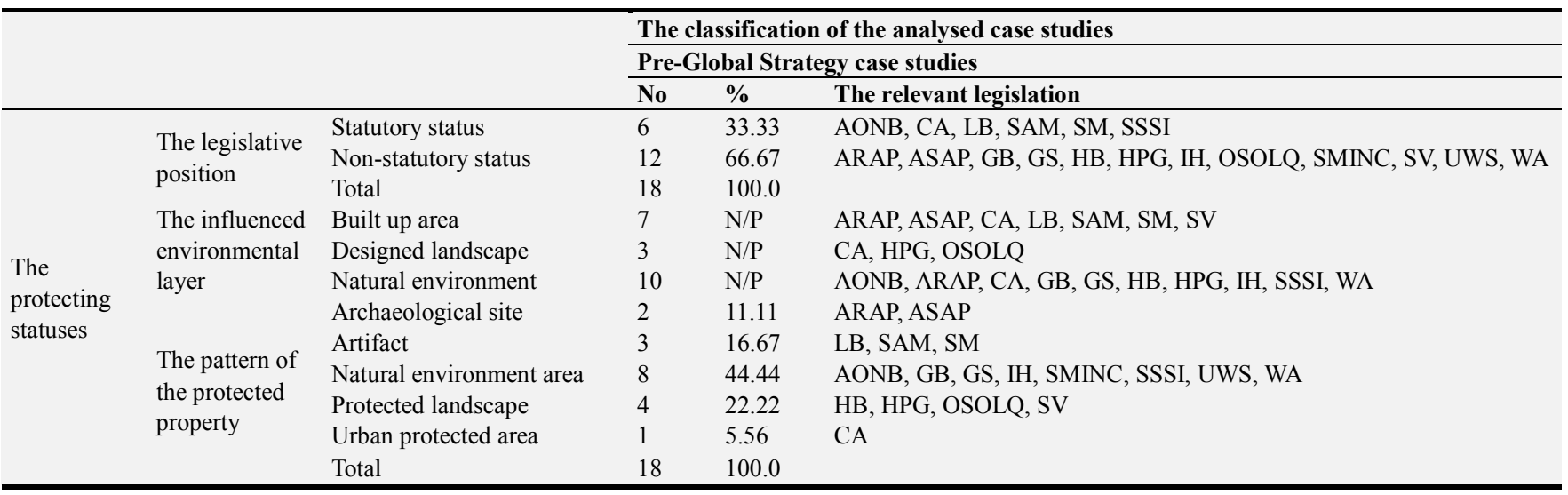




\begin{tabular}{|c|c|c|c|c|c|}
\hline & & & \multicolumn{3}{|c|}{ The classification of the analysed case studies } \\
\hline & & & \multicolumn{3}{|c|}{ Pre-Global Strategy case studies } \\
\hline & & & No & $\%$ & The relevant legislation \\
\hline \multirow{5}{*}{$\begin{array}{l}\text { The relevant } \\
\text { legislation }\end{array}$} & \multirow{5}{*}{$\begin{array}{l}\text { The legislative } \\
\text { group }\end{array}$} & Archaeological law & 1 & 16.67 & The Ancient Monuments and Archaeological Areas Act, 1979 \\
\hline & & Environmental law & 2 & 33.33 & $\begin{array}{l}\text { The National Parks and Access to the Countryside Act, } 1949 \\
\text { The Wildlife and Countryside Act, } 1981\end{array}$ \\
\hline & & Heritage law & 2 & 33.33 & $\begin{array}{l}\text { The Planning (Listed Buildings and Conservation Areas) Act, } 1990 \\
\text { The Planning (Listed Buildings and Conservation Areas) (Scotland) Act, } \\
1997\end{array}$ \\
\hline & & Town planning law & 1 & 16.67 & The Town and Country Planning (Scotland) Act, 1997 \\
\hline & & Total & 6 & 100.0 & \\
\hline
\end{tabular}

\begin{tabular}{|c|c|c|c|c|c|}
\hline & & & \multicolumn{3}{|c|}{ The classification of the analysed case studies } \\
\hline & & & \multicolumn{3}{|c|}{ Post-Global Strategy case studies } \\
\hline & & & No & $\%$ & The relevant legislation \\
\hline \multirow{12}{*}{$\begin{array}{l}\text { The } \\
\text { protecting } \\
\text { statuses }\end{array}$} & \multirow{3}{*}{$\begin{array}{l}\text { The legislative } \\
\text { position }\end{array}$} & Statutory status & 5 & 55.56 & CA, LB, NP, SAM, SSSI \\
\hline & & Non-statutory status & 4 & 44.44 & DL, HL, HPG, SBINC \\
\hline & & Total & 9 & 100.0 & \\
\hline & \multirow{4}{*}{$\begin{array}{l}\text { The influenced } \\
\text { environmental } \\
\text { layer }\end{array}$} & Built up area & 3 & $\mathrm{~N} / \mathrm{P}$ & CA, LB, SAM \\
\hline & & Designed landscape & 4 & $\mathrm{~N} / \mathrm{P}$ & CA, DL, HL, HPG \\
\hline & & Natural environment & 6 & $\mathrm{~N} / \mathrm{P}$ & CA, HL, HPG, NP, SBINC, SSSI \\
\hline & & Archaeological site & 0 & 0.00 & \\
\hline & \multirow{5}{*}{$\begin{array}{l}\text { The pattern of } \\
\text { the protected } \\
\text { property }\end{array}$} & Artifact & 2 & 22.22 & $\overline{\mathrm{LB}}, \mathrm{SAM}$ \\
\hline & & Natural environment area & 3 & 33.33 & NP, SBINC, SSSI \\
\hline & & Protected landscape & 3 & 33.33 & DL, HL, HPG \\
\hline & & Urban protected area & 1 & 11.11 & CA \\
\hline & & Total & 9 & 100.0 & \multirow{6}{*}{$\begin{array}{l}\text { The Ancient Monuments and Archaeological Areas Act, } 1979 \\
\text { The National Parks and Access to the Countryside Act, } 1949 \\
\text { The Wildlife and Countryside Act, } 1981 \\
\text { The Planning (Listed Buildings and Conservation Areas) Act, } 1990 \\
\text { The Planning (Listed Buildings and Conservation Areas) (Scotland) Act, } \\
1997 \\
\text { The Civic Amenities Act, } 1967 \\
\text { The Town and Country Planning Act, } 1971\end{array}$} \\
\hline \multirow{5}{*}{$\begin{array}{l}\text { The relevant } \\
\text { legislation }\end{array}$} & \multirow{5}{*}{$\begin{array}{l}\text { The legislative } \\
\text { group }\end{array}$} & Archaeological law & 1 & 14.29 & \\
\hline & & Environmental law & 2 & 28.57 & \\
\hline & & Heritage law & 2 & 28.57 & \\
\hline & & Town planning law & 2 & 28.57 & \\
\hline & & Total & 7 & 100.0 & \\
\hline
\end{tabular}

Source: Data analysed by the author from the references [23, pp 133-135; 27, Appendix D-Appendix E; 29, pp 110-111; 31, pp 58-63; 34, Section 3 p. 6Section 3 p. 7 Appendix 3; 36, pp 77-78; 38, pp 42-48; 39, pp 35-42].

The third aspect that was adopted to explore the influences of the Global Strategy on the conventional legislative and regulatory measures is the pattern of ownership of the owners of the heritage properties inside the adopted case studies. The findings (Table 4) $[23,27,29,31,34,36,38,39]$ showed that the total number of the key owners of the heritage properties inside the case studies is 50 owners. These key owners include, for instance, Cadw and the City of Edinburgh Council. The indicators that were adopted to evaluate the influences of the Global Strategy on the pattern of ownership are the dependence on single ownership versus the dependence on multiple ownership and the involvement of the official cultural heritage agency and the official natural heritage agency in the ownership of the heritage properties inside the case studies. The findings revealed that the Royal Botanic Gardens in Kew is the only post-Global Strategy case study, whose extent of ownership is limited to the single ownership pattern, since the property is owned by the Queen Elizabeth II. The findings showed that the ownership of all the pre-Global Strategy case studies is limited to the multiple ownership pattern. The findings also showed that the only official cultural heritage agency, which is concerned with the ownership of one of the post-Global Strategy case studies, is
Cadw, while Historic Scotland is the only official cultural heritage agency that is concerned with the ownership of one of the pre-Global Strategy case studies. None of the owners of the eight case studies represents the official natural heritage agency class.

The authorities concerned with the management of the case studies represent the fourth aspect that was adopted to explore the influences of the Global Strategy on the conventional legislative and regulatory measures. The findings (Table 5) $[23,27,29,31,34,36,38,39]$ showed that the total number of the key authorities that are concerned with the management of the case studies is 55 authorities. These authorities involve, for instance, Bath Preservation Trust, Blaenavon Town Council and Scottish Natural Heritage. To evaluate the influences of the Global Strategy, one indicator was adopted, which is the involvement of the official cultural heritage agency and the official natural heritage agency in the management of the case studies. The findings revealed that two of the authorities that are concerned with the management of the pre-Global Strategy case studies represent the official cultural heritage agency class, while none of these authorities represents the official natural heritage agency 
class. The findings also revealed that three authorities that are concerned with the management of the post-Global Strategy case studies represent the official cultural heritage agency class, while two of these authorities represent the official natural heritage agency class.

Table 4. An analysis of the relevant regulatory measures concerning the ownership of the adopted case studies of WHSs.

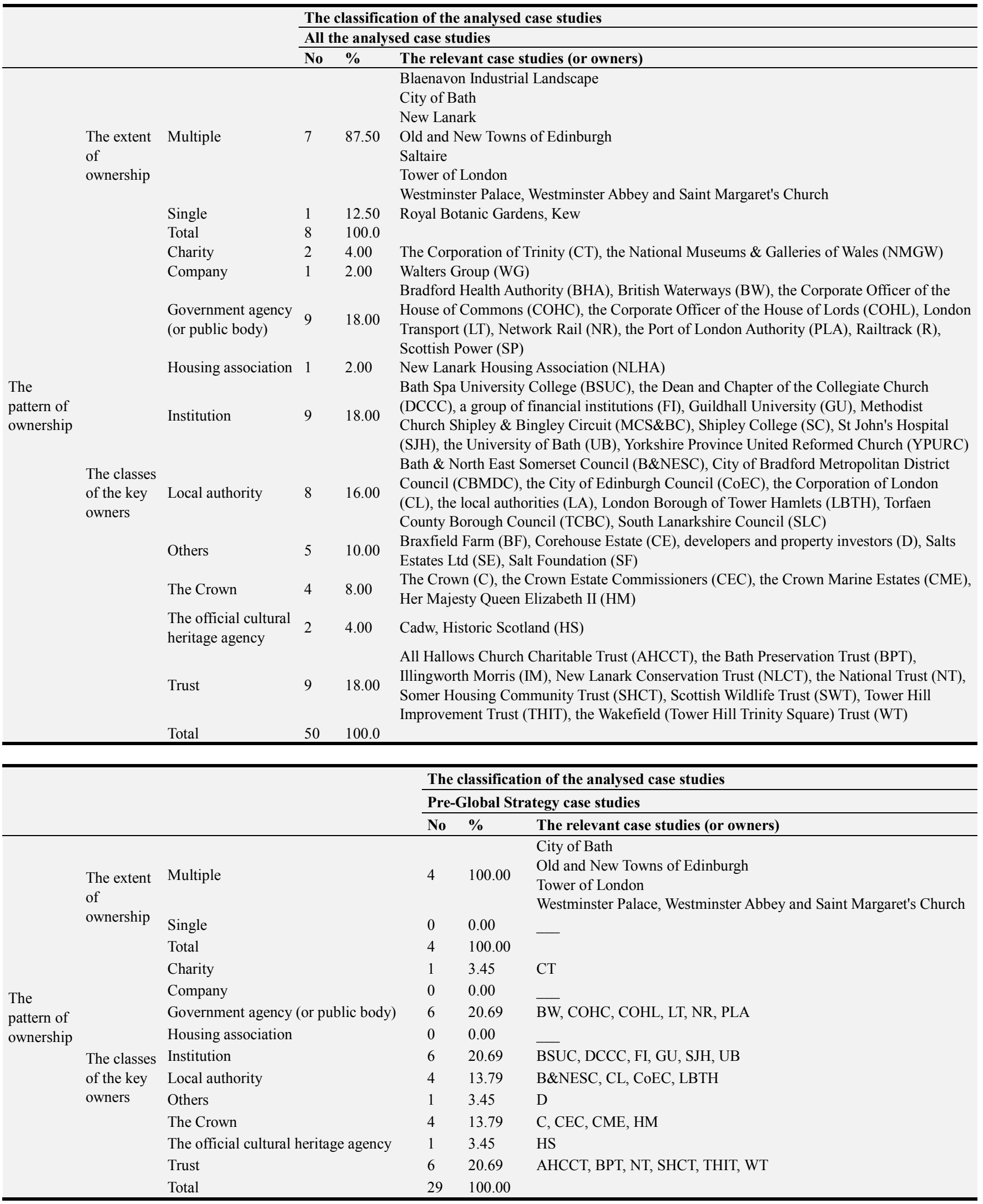




\begin{tabular}{|c|c|c|c|c|c|}
\hline & & & \multicolumn{3}{|c|}{ The classification of the analysed case studies } \\
\hline & & & \multicolumn{3}{|c|}{ Post-Global Strategy case studies } \\
\hline & & & No & $\%$ & The relevant case studies (or owners) \\
\hline \multirow{14}{*}{$\begin{array}{l}\text { The } \\
\text { pattern of } \\
\text { ownership }\end{array}$} & \multirow{3}{*}{$\begin{array}{l}\text { The extent of } \\
\text { ownership }\end{array}$} & Multiple & 3 & 75.00 & $\begin{array}{l}\text { Blaenavon Industrial Landscape } \\
\text { New Lanark } \\
\text { Saltaire }\end{array}$ \\
\hline & & Single & 1 & 25.00 & Royal Botanic Gardens, Kew \\
\hline & & Total & 4 & 100.0 & \\
\hline & \multirow{11}{*}{$\begin{array}{l}\text { The classes of the } \\
\text { key owners }\end{array}$} & Charity & 1 & 4.35 & NMGW \\
\hline & & Company & 1 & 4.35 & WG \\
\hline & & Government agency (or public body) & 4 & 17.39 & BHA, BW, R, SP \\
\hline & & Housing association & 1 & 4.35 & NLHA \\
\hline & & Institution & 3 & 13.04 & MCS\&BC, SC, YPURC \\
\hline & & Local authority & 4 & 17.39 & CBMDC, LA, SLC, TCBC \\
\hline & & Others & 4 & 17.39 & $\mathrm{BF}, \mathrm{CE}, \mathrm{SE}, \mathrm{SF}$ \\
\hline & & The Crown & 1 & 4.35 & $\mathrm{HM}$ \\
\hline & & The official cultural heritage agency & 1 & 4.35 & Cadw \\
\hline & & Trust & 3 & 13.04 & IM, NLCT, SWT \\
\hline & & Total & 23 & 100.0 & \\
\hline
\end{tabular}

Source: Data analysed by the author from the references [23, pp 23-28; 27, Part 2 p. 15; 29, pp 91-94; 31, pp 57-58; 34, Section 3 p. 1; 36, pp 74-75; 38, pp 1113; 39, p. 32].

Table 5. An analysis of the relevant regulatory measures concerning "the management authorities" of the adopted case studies of WHSs.

\begin{tabular}{|c|c|c|c|c|c|}
\hline & & & \multicolumn{3}{|c|}{ The classification of the analysed case studies } \\
\hline & & & \multicolumn{3}{|c|}{ All the analysed case studies } \\
\hline & & & No & $\%$ & The relevant management authorities \\
\hline \multirow{8}{*}{$\begin{array}{l}\text { The } \\
\text { management } \\
\text { authorities }\end{array}$} & \multirow{8}{*}{$\begin{array}{l}\text { The classes of } \\
\text { the key } \\
\text { management } \\
\text { authorities }\end{array}$} & Charity & 1 & 1.82 & National Museums \& Galleries of Wales (NMGW) \\
\hline & & $\begin{array}{l}\text { Government } \\
\text { agency (or public } \\
\text { body) }\end{array}$ & 20 & 36.36 & $\begin{array}{l}\text { Edinburgh City Centre Management Company (ECCMC), Edinburgh World Heritage } \\
\text { (EWH), the London Tourist Board (LTB) } \\
\text { Bradford Health Authority (BHA); British Waterways (BW); Department for Culture, } \\
\text { Media and Sport (DCMS); Environment Agency (EA); Government Office for London } \\
\text { (GOL); House of the Commons (HC); House of the Lords (HL); Historic Royal Palaces } \\
\text { (HRP); the Parliamentary Estates Directorate (PED); Railtrack (R); the Royal Botanic } \\
\text { Gardens (RBG); Royal Commission on the Ancient and Historical Monuments of } \\
\text { Scotland (RCAHM Scotland); Royal Commission on the Ancient and Historical } \\
\text { Monuments of Wales (RCAHM Wales); the Royal Parks Agency (RPA); Scottish } \\
\text { Enterprise Edinburgh and Lothian (SEEL); Scottish Enterprise Lanarkshire (SEL); } \\
\text { Scottish Power (SP); Transport for London (TL); Welsh Development Agency (WDA); } \\
\text { Wales Tourist Board (WTB) }\end{array}$ \\
\hline & & $\begin{array}{l}\text { Housing } \\
\text { association }\end{array}$ & 1 & 1.82 & New Lanark Housing Association (NLHA) \\
\hline & & Local authority & 10 & 10.91 & $\begin{array}{l}\text { The Dean and Chapter of the Collegiate Church of St Peter (DCCC), Royal Armouries } \\
\text { (RA), Shipley College (SC), Saltaire Methodist Church (SMC), United Reformed } \\
\text { Church (URC), Westminster School (WS) } \\
\text { Torfaen County Borough Council (TCBC), Monmouthshire County Council (MCC), } \\
\text { Brecon Beacons National Park (BBNP), Blaenavon Gwent County Borough Council } \\
\text { (BGCBC), Bath \& North East Somerset Council (B\&NESC), South Lanarkshire } \\
\text { Council (SLC), City of Edinburgh Council (CEC), City of Bradford Metropolitan } \\
\text { District Council (CBMDC), Westminster City Council (WCC), Greater London } \\
\text { Authority (GLA) }\end{array}$ \\
\hline & & Others & 4 & 7.27 & $\begin{array}{l}\text { ICOMOS UK, Salts Estate Ltd (SE), Salt Foundation (SF), Saltaire Working Group } \\
\text { (SWG) }\end{array}$ \\
\hline & & $\begin{array}{l}\text { The official } \\
\text { cultural heritage } \\
\text { agency }\end{array}$ & 3 & 5.45 & Cadw, English Heritage (EH), Historic Scotland (HS) \\
\hline & & Trust & 5 & 9.09 & $\begin{array}{l}\text { Bath Preservation Trust (BPT), New Lanark Conservation Trust (NLCT), National } \\
\text { Trust (NT), Somer Housing Community Trust (SHCT), Scottish Wildlife Trust (SWT) }\end{array}$ \\
\hline & & Total & 55 & 100.0 & \\
\hline
\end{tabular}




\begin{tabular}{|c|c|c|c|c|c|}
\hline & & & \multicolumn{3}{|c|}{ The classification of the analysed case studies } \\
\hline & & & \multicolumn{3}{|c|}{ Pre-Global Strategy case studies } \\
\hline & & & No & $\%$ & The relevant management authorities \\
\hline \multirow{11}{*}{$\begin{array}{l}\text { The } \\
\text { management } \\
\text { authorities }\end{array}$} & \multirow{11}{*}{$\begin{array}{l}\text { The classes of the key } \\
\text { management authorities }\end{array}$} & Charity & 0 & 0.00 & \\
\hline & & Company & 3 & 12.50 & ECCMC, EWH, LTB \\
\hline & & Government agency (or public body) & 9 & 37.50 & DCMS, GOL, HC, HL, HRP, PED, RPA, SEEL, TL \\
\hline & & Housing association & 0 & 0.00 & \\
\hline & & Institution & 3 & 12.50 & $\overline{\mathrm{DC}} \mathrm{CC}, \mathrm{RA}, \mathrm{WS}$ \\
\hline & & Local authority & 4 & 16.67 & B\&NESC, CEC, GLA, WCC \\
\hline & & Others & 1 & 4.17 & ICOMOS UK \\
\hline & & The official cultural heritage agency & 2 & 8.33 & EH, HS \\
\hline & & The official natural heritage agency & 0 & 0.00 & 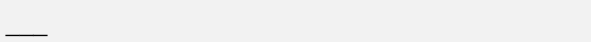 \\
\hline & & Trust & 2 & 8.33 & $\overline{\mathrm{BPT}}$, SHCT \\
\hline & & Total & 24 & 100.00 & \\
\hline
\end{tabular}

\begin{tabular}{|c|c|c|c|c|c|}
\hline & & & \multicolumn{3}{|c|}{ The classification of the analysed case studies } \\
\hline & & & \multicolumn{3}{|c|}{ Post-Global Strategy case studies } \\
\hline & & & No & $\%$ & The relevant management authorities \\
\hline \multirow{10}{*}{$\begin{array}{l}\text { The } \\
\text { management } \\
\text { authorities }\end{array}$} & \multirow{10}{*}{$\begin{array}{l}\text { The classes of the } \\
\text { key management } \\
\text { authorities }\end{array}$} & Charity & 1 & 2.86 & NMGW \\
\hline & & Company & 0 & 0.00 & \\
\hline & & Government agency (or public body) & 11 & 32.35 & $\begin{array}{l}\text { BHA, BW, EA, RBG, SEL, R, RCAHM (Wales), } \\
\text { RCAHM (Scotland), SP, WDA, WTB }\end{array}$ \\
\hline & & Housing association & 1 & 2.94 & NLHA \\
\hline & & Local authority & 6 & 17.65 & BBNP, BGCBC, CBMDC, MCC, SLC, TCBC \\
\hline & & Others & 4 & 11.76 & ICOMOS UK, SE, SF, SWG \\
\hline & & The official cultural heritage agency & 3 & 8.82 & Cadw, EH, HS \\
\hline & & The official natural heritage agency & 2 & 5.88 & $\mathrm{CCW}, \mathrm{SNH}$ \\
\hline & & Trust & 3 & 8.82 & NLCT, NT, SWT \\
\hline & & Total & 34 & 100.0 & \\
\hline
\end{tabular}

Source: Data analysed by the author from the references [23, pp 23-28; 27, Part 2 pp 15-19; 29, pp 91-94; 31, pp 64-66; 34, Section 3 pp 1-3; 36, p. 82; 38, pp $11-13 ; 39$, pp 32-34].

The agreed plans that are used for the management of the case studies represent the fifth aspect that was adopted to explore the influences of the Global Strategy on the conventional legislative and regulatory measures. The analysis of the agreed plans involves the central government and the local authorities' levels. The findings (Table 6) [23, 27, 29, 31, 34, 36, 38, 39] showed that 23 plans are adopted by the management plans of the eight case studies, on the central government level. PPGs and circulars are among the key classes of the plans that are adopted by the management plans of the case studies on the central government level. On the local authorities' level, 21 plans are adopted by the management plans of the eight case studies. These plans involve, for instance, "Central Edinburgh Local Plan, 1997" and "Gwent Structure Plan". The indicators that were adopted to evaluate the influences of the Global Strategy on the agreed plans are "the dependence on the PPGs that are concerned with natural sites" and "the dependence on the circulars that are concerned with natural sites", which are associated with the central government level. The findings revealed that the management plans of the post-Global Strategy case studies are more dependent on the PPGs that are concerned with natural sites than those of the pre-Global Strategy case studies. Four of the PPGs that are adopted by the management plans of the pre-Global Strategy case studies are concerned with cultural sites; which are PPG 6, PPG 15, PPG 16 and NPPG 18 (in Scotland); regarding that PPG 15 and NPPG 18 are almost the same. Three other relevant PPGs are concerned with natural sites; which are PPG 11, NPPG 5 (in Scotland) and NPPG 14 (in Scotland). On the other hand, two of the PPGs that are adopted by the management plans of the post-Global Strategy case studies are concerned with cultural sites, which are PPG 15 and NPPG 18 (in Scotland). Two other relevant PPGs are concerned with natural sites, which are NPPG 5 (in Scotland) and NPPG 14 (in Scotland). The findings also revealed that the management plans of the post-Global Strategy case studies are more dependent on the circulars that are concerned with natural sites than those of the pre-Global Strategy case studies. None of the management plans of the pre-Global Strategy case studies depends on any circulars. On the other hand, the management plans of the post-Global Strategy case studies depend on four circulars, which are "the Scottish Executive Circular 6/1995", which is the only circular concerned with natural sites, and "the Welsh Office Circulars 60/1996, 61/1996 and 1/1998". The Scottish circular provided guidance on the implementation of "Directive 92/43/EEC on the Conservation of Natural Habitats and of Wild Flora and Fauna" (the Habitats Directive) and "Directive 79/409/EEC on the Conservation of Wild Birds" (the Birds Directive) [39]. The Scottish Office Circular 6/1995 was updated in June 2000 and supplemented in 2001 by further guidance on the implementation in Scotland of the Habitats and Bird Directives [40]. "The Welsh Circular 60/1996" is entitled "Planning and the 
Historic Environment: Archaeology and Planning", while "the Welsh Circular 61/1996" is entitled "Planning and the Historic Environment: Historic Buildings and Conservation Areas". Finally, "the Welsh Circular 1/1998" is entitled "Planning and the Historic Environment" [31].

Finally, the relevant policies that are adopted by the agreed plans on the local authorities' level for the management of the case studies represent the sixth aspect that was adopted to explore the influences of the Global Strategy on the conventional legislative and regulatory measures. The only indicator of the relevant policies that was adopted for this analysis is the policies that influence the natural environment and the designed landscape layers versus those that influence the built up area layer. The findings (Table 6) revealed that almost all the plans on the local authorities' level that are adopted by the management plans of both the pre-Global Strategy and the post-Global Strategy case studies involve policies that influence the three environmental layers.

Table 6. An analysis of the relevant regulatory measures concerning "the agreed plans" and "the focus of the relevant policies".

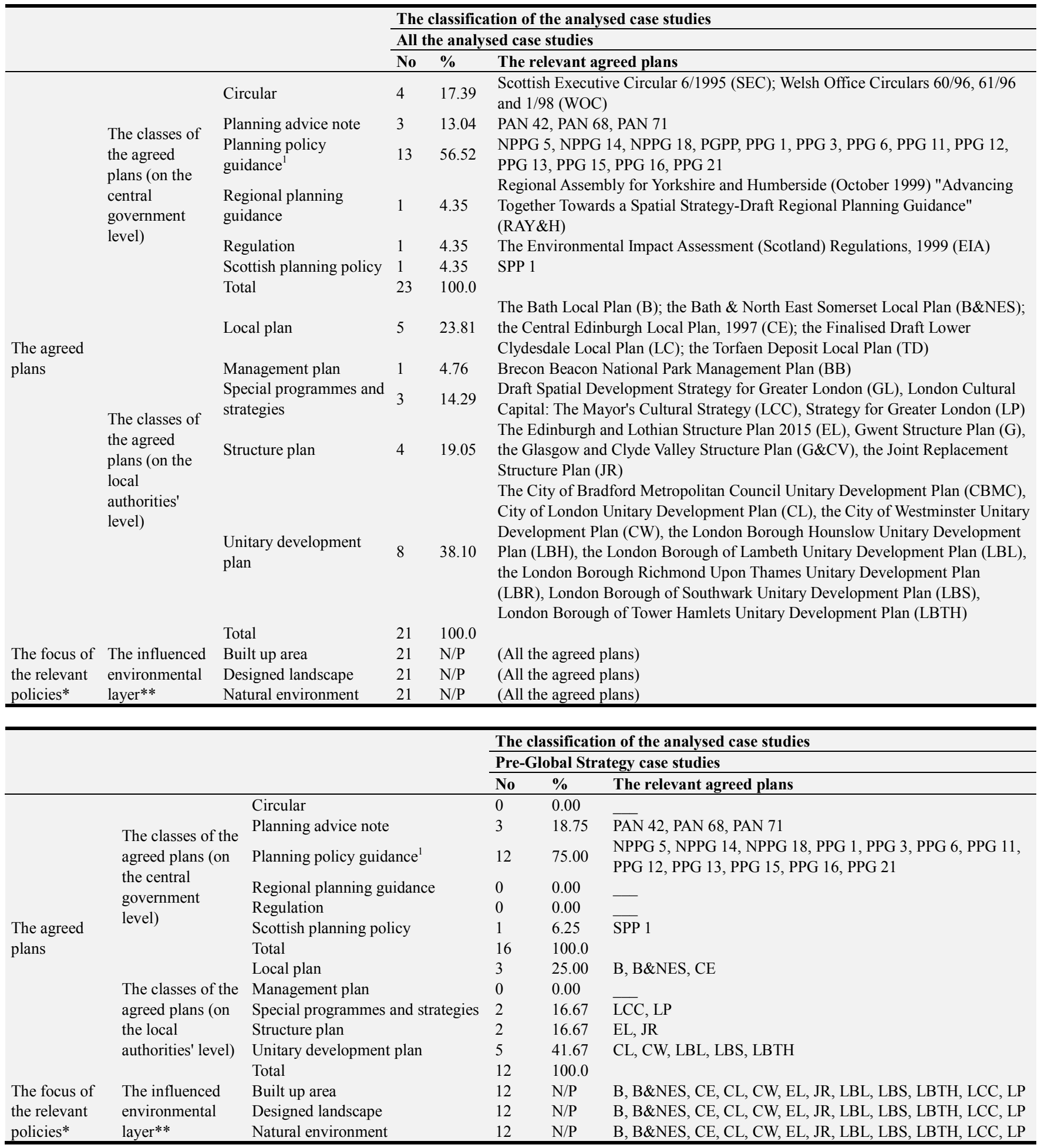




\begin{tabular}{|c|c|c|c|c|c|}
\hline & & & \multicolumn{3}{|c|}{ The classification of the analysed case studies } \\
\hline & & & \multicolumn{3}{|c|}{ Post-Global Strategy case studies } \\
\hline & & & No & $\%$ & The relevant agreed plans \\
\hline \multirow{13}{*}{$\begin{array}{l}\text { The agreed } \\
\text { plans }\end{array}$} & \multirow{8}{*}{$\begin{array}{l}\text { The classes of the agreed } \\
\text { plans (on the central } \\
\text { government level) }\end{array}$} & Circular & 4 & 36.36 & SEC, WOC \\
\hline & & Planning advice note & 0 & 0.00 & \\
\hline & & Planning policy guidance ${ }^{1}$ & 5 & 45.45 & 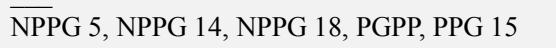 \\
\hline & & Regional planning guidance & 1 & 9.09 & RAY\&H \\
\hline & & Regulation & 1 & 9.09 & EIA \\
\hline & & Scottish planning policy & 0 & 0.00 & 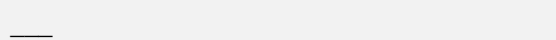 \\
\hline & & Total & 11 & 100.0 & \\
\hline & & Local plan & 2 & 22.22 & LC, TD \\
\hline & \multirow{5}{*}{$\begin{array}{l}\text { The classes of the agreed } \\
\text { plans (on the local } \\
\text { authorities' level) }\end{array}$} & Management plan & 1 & 11.11 & $\mathrm{BB}$ \\
\hline & & Special programmes and strategies & 1 & 11.11 & GL \\
\hline & & Structure plan & 2 & 22.22 & $\mathrm{G}, \mathrm{G} \& \mathrm{CV}$ \\
\hline & & Unitary development plan & 3 & 33.33 & CBMC, LBH, LBR \\
\hline & & Total & 9 & 100.0 & \\
\hline \multirow{3}{*}{$\begin{array}{l}\text { The focus of } \\
\text { the relevant } \\
\text { policies* }\end{array}$} & \multirow{3}{*}{$\begin{array}{l}\text { The influenced } \\
\text { environmental layer** }\end{array}$} & Built up area & 9 & $\mathrm{~N} / \mathrm{P}$ & BB, CBMC, G, G\&CV, GL, LBH, LBR, LC, TD \\
\hline & & Designed landscape & 9 & $\mathrm{~N} / \mathrm{P}$ & $\mathrm{BB}, \mathrm{CBMC}, \mathrm{CL}, \mathrm{G}, \mathrm{G} \& \mathrm{CV}, \mathrm{GL}, \mathrm{LBH}, \mathrm{LBR}, \mathrm{TD}$ \\
\hline & & Natural environment & 8 & $\mathrm{~N} / \mathrm{P}$ & CBMC, G, G\&CV, GL, LBH, LBR, LC, TD \\
\hline
\end{tabular}

[1] The relevant PPGs and NPPGs: NPPG 5: Archaeology and Planning, NPPG 14: Natural Heritage, NPPG 18: Planning and the Historic Environment, PPG 1: General Policy, PPG 3: Housing, PPG 6: Town Centres and Retail Developments, PPG 11: Regional Planning Guidance, PPG 12: Development Plans, PPG

13: Transport, PPG 15: Planning and the Historic Environment, PPG 16: Archaeology and Planning, PPG 21: Tourism

* the policies adopted by the agreed plans on the local authorities' level

** the numbers of the relevant plans

Source: Data analysed by the author from the references [23, pp 132-135; 27, Appendix D pp 1-6; 29, pp 26-28; 31, pp 68-72; 34, Section 3 pp 4-5 Appendix $2 ; 36$, pp 84-90; 38, pp 42-48; 39, pp 35-42].

The first hypothesis, which is relevant to the previous nine indicators, implies the States Parties' need to develop their conventional legislative and regulatory measures to respond to the Global Strategy's recommendation of nominating properties that belong to under-represented categories of heritage properties for listing as WHSs. These under-represented categories involve natural sites and the new types of cultural heritage properties. Therefore, the previous hypothesis implies the need to expand the domain of the post-Global Strategy heritage properties to wider boundaries that incorporate the characteristics of cultural sites with those of natural sites.

It can be inferred from the first hypothesis that the management plans of the post-Global Strategy case studies are expected to be more dependent on non-statutory protecting statuses, the protecting statuses that influence the designed landscape and the natural environment layers, the protecting statuses that are concerned with certain types of heritage properties particularly natural environment areas and protected landscapes, and on the acts that represent environmental laws than those of the pre-Global Strategy case studies. The first hypothesis implies that the post-Global Strategy case studies are more likely to occupy larger areas and to incorporate a wider range of owners, implying that the key characteristics of the post-Global Strategy case studies include the dependence on the multiple ownership pattern and the involvement of the official natural heritage agency in the ownership and management of these case studies. The first hypothesis also implies that the management plans of the post-Global Strategy case studies are expected to be more dependent on the PPGs and the circulars that are concerned with natural sites, and on the policies that influence the natural environment and the designed landscape layers than those of the pre-Global Strategy case studies.

The previous arguments indicate that five findings contradict with the first hypothesis. These are the findings that are related to the indicators concerned with the dependence on non-statutory protecting statuses, the protecting statuses that influence the designed landscape and natural environment layers, the protecting statuses that are concerned with natural environment areas and protected landscapes, the dependence on environmental laws, and the involvement of the official cultural heritage agency and the official natural heritage agency in the ownership of the heritage properties in the case studies. The previous arguments indicate that the finding that is related to the indicator concerned with the dependence on single ownership versus the dependence on multiple ownership does not seem to contradict with the first hypothesis though the existence of a post-Global Strategy case study, whose extent of ownership is the single ownership pattern, weakens its support for this hypothesis. The previous arguments indicate that three findings support the first hypothesis. These are the findings that are related to the indicators concerned with the involvement of the official cultural heritage agency and the official natural heritage agency in the management of the case studies, the dependence on the PPGs concerned with natural sites in the management of the case studies, and the dependence on the circulars concerned with natural sites in the management of the case studies. The previous arguments also indicate that one finding, which is the finding related to the indicator concerned with the policies that influence the natural environment and the designed landscape layers versus those that influence the built up area layer, seem to be insignificant.

The previous preview shows that five findings of this study contradict with the first hypothesis, while other four findings support it. Consequently, the previous findings seem to emphasize the invalidity of the first hypothesis, implying the existence of very limited influences of the Global Strategy on the conventional legislative and regulatory 
measures. The previous findings seem to indicate that many States Parties, such as the United Kingdom, still depend on their conventional legislative and regulatory measures to provide protection for the newly inscribed post-Global Strategy WHSs. The contradiction with the implications of the first hypothesis might be attributed to the existence of World Heritage Cities within the categories of the pre-Global Strategy case studies. The management of World Heritage Cities seems to require adopting a very broad array of management tools and measures. The list of the protecting statuses that have been adopted by the management plan of "Old and New Towns of Edinburgh" WHS reflects the breadth of the measures that are required for the management of World Heritage Cities. These protecting statuses involve, for instance, "Open Space of Outstanding Landscape Quality", which is a non-statutory status; and "Site of Special Scientific Interest, SSSI", which has been granted to two areas inside this WHS. "Holyrood Park/Meadowfield Park" is an example of these two areas.

\subsection{The Complexity of the Management of the Post-Global Strategy WHSs}

To evaluate the complexity of the management of the postGlobal Strategy case studies, seven indicators were adopted (Table 2). The first indicator is concerned with the area of the case study. The findings (Table 1) revealed that the average area of the post-Global Strategy case studies is slightly larger than that of the pre-Global Strategy case studies. The second indicator is concerned with the total number of the protecting statuses that are adopted by the management plans of the case studies. The findings (Table 3) revealed that the number of the protecting statuses that are adopted by the management plans of the pre-Global Strategy case studies is larger than that of the post-Global Strategy case studies. The third indicator is concerned with the number of the case studies that are owned by multiple owners versus the number of the case studies that are owned by a single owner. The findings (Table 4) revealed that the number of the pre-Global Strategy case studies, whose extent of ownership is the multiple ownership pattern is larger than that of the post-Global Strategy case studies. The fourth indicator is concerned with the total number of owners of the case studies. The findings (Table 4) revealed that the number of the key owners of the pre-Global Strategy case studies is larger than the corresponding number of the post-Global Strategy case studies. The fifth indicator is concerned with the total number of the authorities that are involved with the management of the case studies. The findings (Table 5) showed that the number of the key authorities that are concerned with the management of the post-Global Strategy case studies is larger than that of the pre-Global Strategy case studies. The sixth indicator is concerned with the total number of the agreed plans that are adopted on the central government level and are used for the management of the case studies. The findings (Table 6), in relation to the sixth indicator, showed that the number of the relevant plans that are adopted on the central government level for the management of the pre-Global
Strategy case studies is larger than that of the post-Global Strategy case studies. Finally, the seventh indicator is concerned with the total number of the agreed plans that are adopted on the local authorities' level and are used for the management of the case studies. The findings (Table 6), in relation to the seventh indicator, showed that the number of the plans that are adopted on the local authorities' level for the management of the pre-Global Strategy case studies is larger than that of the post-Global Strategy case studies.

The second hypothesis, which is relevant to the seven indicators, implies that the management of the post-Global Strategy case studies is expected to be more complex than that of the pre-Global Strategy case studies. The second hypothesis seems to imply that the area and the number of the adopted protecting statuses of the post-Global Strategy case studies are expected to be larger than those of the preGlobal Strategy case studies. It can be inferred from the second hypothesis that the multiple ownership pattern is expected to prevail the patterns of ownership of the postGlobal Strategy case studies in comparison with the preGlobal Strategy case studies. The complexity of the management of the post-Global Strategy case studies implies the involvement of more owners and more management authorities in the management of these case studies. The complexity of the management of the post-Global Strategy case studies also implies adopting more plans, on the central government and the local authorities' levels, to provide the necessary protection for the heritage properties in these case studies. The previous arguments indicate that only two findings, which are related to the indicators concerned with the total area of the case studies and the total number of the authorities that are involved with the management of the case studies, support the second hypothesis, while the other findings contradict with it. Consequently, the previous findings seem to confirm the invalidity of the second hypothesis. The existence of World Heritage Cities among the categories representing the pre-Global Strategy case studies might explain the invalidity of the second hypothesis.

\section{Conclusions}

A study commissioned by the World Heritage Centre revealed that the WHL suffers from representational gaps represented by the under-representativeness of particular categories of heritage properties and the heritage of some UNESCO's regions. To resolve these representational gaps, the World Heritage Committee adopted the Global Strategy for a balanced, representative and credible WHL in 1994 and carried out significant amendments to the OGs of 2005. These amendments involve the recommendation that States Parties submit their Tentative Lists [41] and the recommendation that States Parties nominate properties, which fall into underrepresented heritage categories for listing as WHSs. Responding to the previous challenges implies that States Parties are expected to develop their conventional legislative and regulatory measures in order to provide protection for these new categories of heritage properties. 
The findings revealed the limited influences of the Global Strategy on the conventional legislative and regulatory measures that are adopted to provide the required protection for the inscribed WHSs. The findings indicated that the compliance with the prerequisites of the Global Strategy has not led to the development of further advanced legislative and regulatory measures. The previous findings do not seem to support the first hypothesis, which implies that States Parties have to develop their conventional legislative and regulatory measures to meet the challenges of the Global Strategy. The previous findings might also be attributed to the States Parties' limited interest in developing their conventional legislative and regulatory measures that are used to provide protection for WHSs, or their limited interest in the arguments on the Global Strategy. Consequently, the previous findings do not imply that there is no requirement for States Parties to develop their conventional legislative and regulatory measures in order to provide protection for the new patterns of WHSs that represent the response to the prerequisites of the Global Strategy. The results indicated that the management of the pre-Global Strategy WHSs is more complex than that of the post-Global Strategy WHSs, which reflect a response to the requirements of the Global Strategy. The previous finding emphasizes the invalidity of the second hypothesis, which implies that the management of the WHSs that comply with the prerequisites of the Global Strategy is expected to be more complex than that of the pre-Global Strategy WHSs. The existence of World Heritage Cities among the categories of the pre-Global Strategy case studies might explain the invalidity of the previous two hypotheses.

The findings revealed the British experience's obvious dependence on non-statutory protecting statuses to provide protection for the inscribed WHSs. The findings also reflected the World Heritage Committee's tolerance that allows the dependence on non-statutory mechanisms for the protection of WHSs. The study suggests the need to develop the non-statutory protecting statuses that are used in the United Kingdom to provide protection for inscribed WHSs and the need to replace these less efficient non-statutory protecting statuses by further developed statutory mechanisms. The study recommends that States Parties to the World Heritage Convention, such as the United Kingdom and Egypt, have to develop the conventional legislative and regulatory measures that they use to provide protection for inscribed WHSs or newly nominated ones in order to meet the new requirements and the new challenges of the Global Strategy.

\section{References}

[1] UNESCO, Operational Guidelines for the Implementation of the World Heritage Convention. Paris: United Nations Educational Scientific and Cultural Organization, 2017.

[2] UNESCO World Heritage Centre-Global Strategy [Online]. Paris: UNESCO World Heritage Centre, 2019. Available from: http://whc.unesco.org/en/globalstrategy [Accessed 20 August 2019].
[3] UNESCO, Operational Guidelines for the Implementation of the World Heritage Convention. Paris: United Nations Educational Scientific and Cultural Organization, 2005.

[4] UNESCO, Item 14 of the Provisional Agenda: Tentative Lists of States Parties submitted as of 15 may 2004 in conformity with the Operational Guidelines. Paris: United Nations Educational Scientific and Cultural Organization, 2004.

[5] Aplin, Graeme, Heritage, Identification, Conservation, and Management. South Melbourne: OXFORD UNIVERSITY PRESS, 2002.

[6] Gfeller, Aurélie Elisa (2015). Anthropologizing and idigenizing heritage: The origins of the UNESCO Global Strategy for a representative, balanced and credible World Heritage List. Journal of Social Archaeology. 15 (3), 366-386.

[7] Labadi, Sophia (2005). A review of the Global Strategy for a balanced, representative and credible World Heritage List 1994-2004. Conservation and Management of Archaeological Sites. 7 (2), 89-102.

[8] UNESCO World Heritage Centre, Glossary of World Heritage Terms, A Glossary of Terms relating to the Implementation of the World Heritage Convention. Paris: UNESCO World Heritage Centre, 1997.

[9] Expert Meeting on the Global Strategy [Online]. Paris: UNESCO World Heritage Centre, 1994. Available from: http://whc.unesco.org/archive/global94.htm [Accessed 20 August 2019].

[10] UNESCO, Item 10 of the Provisional Agenda: Progress Report, Synthesis and Action Plan on the Global Strategy for a representative and credible World Heritage List. Paris: United Nations Educational Scientific and Cultural Organization, 1998.

[11] Yang, Minja and Pharès, Jehanne, "Safeguarding and Development of World Heritage Cities" in UNESCO World Heritage Centre, World Heritage Papers 9, Partnership for World Heritage Cities, Cultures as a Vector for Sustainable Urban Development; World Heritage 2002, Shared Legacy, Common Responsibility, Associated Workshops; 11-12 November 2002 Urbino, Pesaro. Paris: UNESCO World Heritage Centre, 2003, 10-14.

[12] Anon., "Annex B, Urban Heritage on the World Heritage List" in UNESCO World Heritage Centre, World Heritage Papers 9, Partnership for World Heritage Cities, Cultures as a Vector for Sustainable Urban Development; World Heritage 2002, Shared Legacy, Common Responsibility, Associated Workshops; 11-12 November 2002 Urbino, Pesaro. Paris: UNESCO World Heritage Centre, 2003, 105-110.

[13] Rössler, Mechtild, "Linking Nature and Culture: World Heritage Cultural Landscapes" in UNESCO World Heritage Centre, World Heritage Papers 7, Cultural Landscapes: the Challenges of Conservation; World Heritage 2002, Shared Legacy, Common Responsibility, Associated Workshop; 11-12 November 2002 Ferrara. Paris: UNESCO World Heritage Centre, 2003, 10-15.

[14] Ores, Ron van, "Introduction to the Programme on Modern Heritage" in UNESCO World Heritage Centre, World Heritage Papers 5, Identification and Documentation of Modern Heritage; Expert Meeting on Modern Heritage, October 2001 Paris. Paris: UNESCO World Heritage Centre, 2003, 8-14. 
[15] UNESCO, Information document: Report of the Expert Meeting on Desert Landscapes and Oasis Systems. Paris: United Nations Educational Scientific and Cultural Organization, 2001.

[16] Works of Antoni Gaudí - UNESCO World Heritage Centre [Online]. Paris: UNESCO World Heritage Centre, 2019. Available from: http://whc.unesco.org/en/list/320 [Accessed 20 August 2019].

[17] Fowler, Peter, "World Heritage Cultural Landscapes, 19922002: a Review and Prospect" in UNESCO World Heritage Centre, World Heritage Papers 7, Cultural Landscapes: the Challenges of Conservation; World Heritage 2002, Shared Legacy, Common Responsibility, Associated Workshops; 1112 November 2002 Ferrara. Paris: UNESCO World Heritage Centre, 2003, 16-31.

[18] Fowler, P. J., World Heritage Cultural Landscapes, 1992-2002. Paris: UNESCO World Heritage Centre, 2003.

[19] Anon., "Annex A, Modern heritage properties on the World Heritage List (as at July 2002)" in UNESCO World Heritage Centre, World Heritage Papers 5, Identification and Documentation of Modern Heritage; Expert Meeting on Modern Heritage, October 2001 Paris. Paris: UNESCO World Heritage Centre, 2003, 140.

[20] Grementieri, Fabio, "The presentation of nineteenth- and twentieth-century heritage" in UNESCO World Heritage Centre, World Heritage Papers 5, Identification and Documentation of Modern Heritage; Expert Meeting on Modern Heritage, October 2001 Paris. Paris: UNESCO World Heritage Centre, 2003, 82-89.

[21] Roosmalen, Pauline van, "Changing views on colonial heritage" in UNESCO World Heritage Centre, World Heritage Papers 5, Identification and Documentation of Modern Heritage; Expert Meeting on Modern Heritage, October 2001 Paris. Paris: UNESCO World Heritage Centre, 2003, 122-129.

[22] Rodwell, Dennis (2002). The World Heritage Convention and the Exemplary Management of Complex Heritage Sites. Journal of Architectural Conservation. 8 (3), 40-60.

[23] Bath and North East Somerset Council, City of Bath World Heritage Site Management Plan. Bath: Bath and North East Somerset Council, 2004.

[24] City of Bath-UNESCO World Heritage Centre [Online]. Paris: UNESCO World Heritage Centre, 2019. Available from: http://whc.unesco.org/en/list/428 [Accessed 5 August 2019].

[25] Edinburgh World Heritage, The Old and New Towns of Edinburgh World Heritage Site Management Plan. Edinburgh: Edinburgh World Heritage, 2005.

[26] Old and New Towns of Edinburgh-UNESCO World Heritage Centre [Online]. Paris: UNESCO World Heritage Centre, 2019. Available from: http://whc.unesco.org/en/list/728 [Accessed 5 August 2019].

[27] Department for Culture, Media and Sport, Tower of London World Heritage Site, Management Plan, Final Draft for Consultation. London: Department for Culture, media and Sport, 2003.

[28] Tower of London-UNESCO World Heritage Centre [Online].
Paris: UNESCO World Heritage Centre, 2019. Available from: http://whc.unesco.org/en/list/488 [Accessed 20 August 2019].

[29] Atkins, The Palace of Westminster and Westminster Abbey including St. Margaret's Church, Westminster World Heritage Site Management Plan, Consultation Draft. Surrey: Atkins, 2004.

[30] Westminster Palace, Westminster Abbey and Saint Margaret's Church-UNESCO World Heritage Centre [Online]. Paris: UNESCO World Heritage Centre, 2019. Available from: http://whc.unesco.org/en/list/426 [Accessed 6 August 2019].

[31] Torfaen County Borough Council, Nomination of the BLAENAVON INDUSTRIAL LANDSCAPE for inclusion in the WORLD HERITAGE LIST. Torfaen: Torfaen County Borough Council, 1999.

[32] Blaenavon Industrial Landscape-UNESCO World Heritage Centre [Online]. Paris: UNESCO World Heritage Centre, 2019. Available from: http://whc.unesco.org/en/list/984 [Accessed 5 August 2019].

[33] New Lanark-UNESCO World Heritage Centre [Online]. Paris: UNESCO World Heritage Centre, 2019. Available from: http://whc.unesco.org/en/list/429 [Accessed 6 August 2019].

[34] Royal Botanic Gardens, Kew, Royal Botanic Gardens, Kew, Candidate World Heritage Site, Draft Management Plan. Surrey: Royal Botanic Gardens, Kew, 2002.

[35] Royal Botanic Gardens, Kew-UNESCO World Heritage Centre [Online]. Paris: UNESCO World Heritage Centre, 2019. Available from: http://whc.unesco.org/en/list/1084 [Accessed 6 August 2019].

[36] Department for Culture, Media and Sport, Draft Management Plan, NOMINATION OF SALTAIRE FOR INCLUSION IN THE WORLD HERITAGE LIST. London: Department for Culture, Media and Sport, 2000.

[37] Saltaire UNESCO World Heritage Centre [Online]. Paris: UNESCO World Heritage Centre, 2019. Available from: http://whc.unesco.org/en/list/1028 [Accessed 9 August 2019].

[38] Edinburgh World Heritage, Management Plan for the Old and New Towns of Edinburgh World Heritage Site, Final Draft April 2005. Edinburgh: Edinburgh World Heritage, 2005.

[39] Historic Scotland, NEW LANARK WORLD HERITAGE SITE MANAGEMENT PLAN 2003-2008, CONSULTATION DRAFT. Edinburgh: Historic Scotland, 2003.

[40] Scottish Executive Environment and Rural Affairs Department, European Protected Species, Development Sites and the Planning System; Interim guidance for local authorities on licensing arrangements. Edinburgh: Scottish Executive Environment and Rural Affairs Department, 2001.

[41] Abdel Tawab, Ayman G., “Article 55 Directions: Developing and Revising Tentative Lists and their Potential Influences" in Wallin, Paul and Martinsson, Helene (eds.), THE GOTLAND PAPERS, Selected Papers from the VII International Conference on Easter Island and the Pacific, Migration, Identity, and Cultural Heritage, VII International Conference on Easter Island and the Pacific; Migration, Identity and Cultural Heritage; Proc. Intern. Conf., Visby, 20-25 August 2007. Visby: Gotland University Press. 